\title{
Co-occurrence of Herpes simplex virus 1 and 2 in patients suspected with different neurological ailments in Karachi
}

\author{
Aneela Taj and Nusrat Jamil* \\ Department of Microbiology, University of Karachi, Pakistan
}

\begin{abstract}
Background: Viral meningitis (VM) is the most prevalent type of meningitis and mainly characterized by the meningeal inflammation caused by Herpes simplex viruses. Cerebrospinal fluid (CSF) samples of patients of neurological diseases were screened for viral etiological agents i.e. Herpes simplex virus 1 (HSV1) and Herpes simplex virus 2 (HSV2) and occurrence of co-infection of both the viral strains.

Methods: $92 \mathrm{CSF}$ samples were collected from different mentally ailed patients admitted in the local hospitals of Karachi. Out of which 30 bacteria negative CSF samples were selected for the screening of viral etiology. Total cellular DNA extraction was done by the conventional methods. HSV1 and HSV2 specific primers targeting the glycoprotein $\mathrm{G}$ gene were used for the viral detection by polymerase chain reaction (PCR).

Results: Presence of HSV2 was confirmed in (26.6\%) clinical samples of CSF whereas HSV1 was found in only (6.6\%) of samples. (36.6\%) CSF samples demonstrated the mixed viral infection of HSV1 and HSV2. While (23.33\%) CSF samples were found negative for any viral etiology. Total cellular DNA quantification revealed the increased concentration i.e. $802 \mu \mathrm{g} / \mathrm{ml}$ in HSV2 infections.

Conclusion: Findings of the present study demonstrated that the detection and diagnosis of neurological infections on the basis of clinical signs are not sufficient. Therefore, existence of viral etiological agents must be checked subsequent to bacterial culture to avoid the misdiagnosis and wrong treatment of the CNS infections.
\end{abstract}

\section{Introduction}

Blood Brain Barrier (BBB) at anatomic level refers to a connected structure that forms a barrier between blood and brain. It separates the central nervous system (CNS) from vascular compartment and regulates the intercellular passage of blood-borne substances and cells into the brain $[1,2]$. One of the key events in the pathogenesis of CNS infections is the entry of microbes either to the central compartment or in cerebrospinal fluid (CSF) by breaching the BBB [3]. The invasion of the CNS by viruses causes a variety of pathological manifestation i.e. viral encephalitis [2]. Herpes viruses composed of a group of viruses that are large, DNA-containing, enveloped viruses that are an important cause of CNS infections [4-7]. Among these viruses, Herpes simplex viruses (HSVs) accounts for approximately 2 to $19 \%$ of all cases of encephalitis and 20 to $25 \%$ of all cases of necrotizing encephalitis [8-10]. In addition to this, HSVs cause various acute, sub-acute and chronic neurological diseases which are associated with significant morbidity and even mortality in both immunocompetent and immunocompromised subjects. HSVs cause neurological dysfunction and tissue damage directly by infecting neural cells, peripheral nerves or spinal ganglia, and/or through immunologically-mediated mechanisms [11-14]. Herpes simplex 1 (HSV1) and less frequently Herpes simplex 2 (HSV2) are recognized to cause encephalitis, while HSV-2 also cause acute meningitis [14].

An extensive literature review revealed that most of the studies reported in recent past are confined to the individual cases of mixed Herpesvirus infection (Herpes simplex virus (HSV) plus Epstein Barr virus (EBV) and Cytomegalovirus plus EBV) in CNS $[15,16]$. Nonetheless, Xue et al. and Anderson et al. [17,18] have recently reported the coinfection of Herpes simplex virus 2 (HSV2) plus CMV and Herpes simplex virus 1 (HSV1) and HSV2 $[17,18]$. Furthermore, to the extent that local reports related to viral infections of CNS are concerned, recently Jawaid et al. has reported the presence of viral meningitis in 18 patients in Pakistan [19].

Therefore, present study was designed to analyze the CSF of the patients of neurological disease for the determination of viral etiology through detecting the presence of HSV1 and HSV2 and occurrence of their coinfection.

\section{Materials and methods}

\section{Chemicals}

Unless otherwise stated, all the analytical grade chemicals were purchased from Merck, Frankfurter, Darmstadt, Germany. Polymerase chain reaction (PCR) reaction mix was purchased from Promega, Madison, Wisconsin, USA.

\section{Study group}

Present study is a sub-analysis of cerebrospinal fluid (CSF) samples collected randomly from the patients admitted with neurological ailments in the two major government hospitals of Karachi, Pakistan [20]. Sample collection was carried out subsequent to the consent and approval of lab authorities. All informed patients were given

${ }^{\star}$ Correspondence to: Nusrat Jamil, Department of Microbiology, University of Karachi, Karachi- 75270, Pakistan, Tel: +92-300-2162465, E-mail: nusrat_91@ yahoo.com

Key words: Herpes simplex virus 1, Herpes simplex virus 2, coinfection, viral meningitis, cerebrospinal fluid, central nervous system, diagnosis

Received: April 30, 2018; Accepted: May 07, 2018; Published: May 10, 2018 
a questionnaire for their consent prior to inclusion in the study. All procedures performed in this study involving human participants were in accordance with the 1964 Helsinki declaration and its later amendments. All the collected CSF samples were aliquotted and stored at $-80^{\circ} \mathrm{C}$ immediately. CSF samples proven the absence of meningitis bacteria subsequent to the microbiological processing [20] were included in the present study. Total 30 CSF samples were checked for the presence of Herpes simplex virus 1 (HSV1) and Herpes simplex virus 2 (HSV2) and for the occurrence of their coinfection.

\section{Clinical investigations}

Data for the routine diagnostic tests performed for CSF samples was obtained from the lab. Biochemical tests i.e. protein and glucose estimation were performed using photometric method on Selectra E, Merck. Furthermore, haematological tests including WBCs, RBCs and differential leukocyte counts were performed using standard methods.

\section{Total DNA extraction}

For total cellular DNA extraction, $150 \mu$ l of CSF was mixed with $150 \mu \mathrm{l}$ of cell lysis buffer (containing $2 \mathrm{mg} / \mathrm{ml}$ proteinase $\mathrm{K}$ in $1 \mathrm{M}$ Tris- $\mathrm{HCl}$ ( $\mathrm{pH} 8.0$ ), $0.1 \mathrm{mM}$ ethylenediamine tetraacetic acid, and $5 \%$ (w/v) sodium dodecyl phosphate) and incubated at $37^{\circ} \mathrm{C}$ for 1 hour. The lysed samples were extracted twice with equal volume of phenol and chloroform-isoamyl alcohol (24:1), both steps followed by a centrifugation step at $5000 \mathrm{rpm}$ for $2 \mathrm{~min}$. DNA was precipitated by adding 2.5 volumes of chilled absolute ethanol and placed overnight at $-20^{\circ} \mathrm{C}$. The DNA was centrifuged at $13,000 \mathrm{rpm}$ for 20 minutes at $4^{\circ} \mathrm{C}$. The DNA pellet was washed with $70 \%$ ethanol.

After air-drying, the DNA was dissolved in $25 \mu \mathrm{l}$ of sterile D/W. Extracted DNA was quantified spectrophotometrically at $260 \mathrm{~nm}$.

\section{Conventional PCR reaction}

PCR amplification was carried out using GoTaq ${ }^{\circ}$ Green Master Mix (Promega). For each PCR reaction, the $25 \mu$ l reaction mixture contained $12.5 \mu \mathrm{l}$ of Master Mix, $6.5 \mu \mathrm{l}$ of the D/W, $2 \mu \mathrm{l}$ of each forward and reverse primer and 1.7-194 $\mu \mathrm{g}$ of the template. The PCR temperature profile used for two different sets of viral specific primers targeting glycoprotein G genes of HSV1 and HSV2 respectively is summarized in table 1 . Amplified PCR products were detected by agarose gel (2\%) electrophoresis and gels were visualuzed using GelDoc (BioRed, USA) after staining with ethidium bromide.

\section{Statistics}

Statistical data are expressed as mean \pm SEMs. The significance $(p$ $<0.05$ ) of between group differences was analysed using the two-way ANNOVA tool in SPSS version 15.

\section{Results}

\section{Clinical investigations}

Clinical investigations of the 30-cerebrospinal fluid (CSF) samples revealed that HSV1 infection was prevalent in male subjects whereas most of the female subjects were found infected with HSV2 virus. On contrary, coinfection of HSV1+2 was found significantly prevalent in male patients (Figure 1A). Furthermore, HSV1 was found positive in more than 40 years of age group, while patients of 13 to 24 years of age group revealed the HSV2 infection. Moreover, 25 to 40 years of age group of patients was found positive for the viral coinfection (Figure 1B). In addition to this, most of the patients having fever at the time of sample collection found positive for HSV etiology (Figure 1C).
Table 1. Primers used for Herpes Simplex Virus Amplification.

\begin{tabular}{|c|c|c|c|c|c|}
\hline S. No & Virus & $\begin{array}{l}\text { Primer } \\
\text { Name }\end{array}$ & Sequence & $\mathbf{T m}$ & Reference \\
\hline 01 & \multirow{4}{*}{ 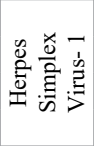 } & HS1F3 & GCCGTTGTTCCCATTATCCC & \multirow{2}{*}{$59^{\circ} \mathrm{C}$} & \multirow{8}{*}{ [30] } \\
\hline 02 & & HS1B3 & TACTTGGCATGGGGGGTG & & \\
\hline 03 & & HS1LPF & TTGGTGGGAACCCCCGATAC & $57^{\circ}$ & \\
\hline 04 & & HS1LPB & AACATGACCCAGACCGGCAC & נו & \\
\hline 05 & \multirow{4}{*}{ 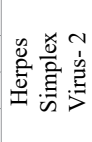 } & $\mathrm{HS} 2 \mathrm{~F} 3$ & GGCCTTGACCGAGGACAC & \multirow{2}{*}{$58^{\circ} \mathrm{C}$} & \\
\hline 06 & & HS2B3 & CGACTCCACGGATGCAGT & & \\
\hline 07 & & HS2LPF & GCCGACACAGGGAGGGGCGT & \multirow{2}{*}{$64^{\circ} \mathrm{C}$} & \\
\hline 08 & & HS2LPB & GATGGCCACACAAGCCGCAA & & \\
\hline
\end{tabular}

\section{Biochemical and haematological profiling}

Next, these samples were analyzed for biochemical profiling. It is worth to mention here in that all the collected CSF samples showed normal $\mathrm{pH}$. Furthermore, the quantification of protein revealed the highest protein content in HSV2 infection whereas highest content of glucose was found positive in HSV1+2 coinfection group. Another set of experiment was delineated to investigate the hematological profiling of the CSF samples included in the study reported herein. It is significant to note that most of the RBCs were seen in the CSF samples of HSV2 group while samples showed HSV1 infection revealed the presence of WBCs. Furthermore, most of the lymphocytes were found in the HSV2 infection whereas, samples showed HSV1 infection was revealed highest number of neutrophils (Table 2).

\section{Cellular DNA quantification}

Total thirty cerebrospinal fluid (CSF) samples were screened for the presence of viral etiology. Cellular DNA quantification profile of these CSF samples showed that 7 samples (33.3\%) high yield of DNA i.e. $805.82 \mu \mathrm{g} / \mathrm{ml}$. Whereas the amount of quantified DNA in 14 samples (66.67\%) was found to be of moderate concentration i.e. 49.53 $\mu \mathrm{g} / \mathrm{ml}$. It is significant to mention herein that the highest DNA yield was found in CSF samples that found positive for the presence of HSV2 exclusively (Table 2).

\section{HSV infection profile}

Furthermore, the results of PCR (Figure 2) highlighted that out of this presence of HSV2 was confirmed in $(26.6 \%)$ clinical samples of CSF whereas HSV1 was found in only (6.6\%) of samples. Conversely, (36.6\%) CSF samples demonstrated the mixed viral infection of HSV1 and HSV2. While (23.33\%) CSF samples were found negative for any viral etiology.

\section{Discussion}

Results of previous study undertaken by the same authors [20] revealed the existence of total 30 cerebrospinal fluid (CSF) samples that did not yield any bacterial etiology upon conventional methods for bacterial culture. Therefore, interest to determine the association of viral pathogens with the neurological disorders and their existence pattern had warranted us to proceed further. To accomplish this total thirty bacteriologically negative CSF samples were selected to explore the presence of Herpes simplex virus 1 (HSV1), Herpes simplex virus 2 (HSV2) and their coinfection.

Viral infections of CNS cause a variety of pathological manifestation. Herpes simplex viruses (HSVs) are the most common cause of aseptic meningitis. Humans are the only reservoir of HSV [21,22]. High fever and headache are the cardinal symptoms, but CSF of virally infected patients can be found clear in appearance due to the lack of sepsis 

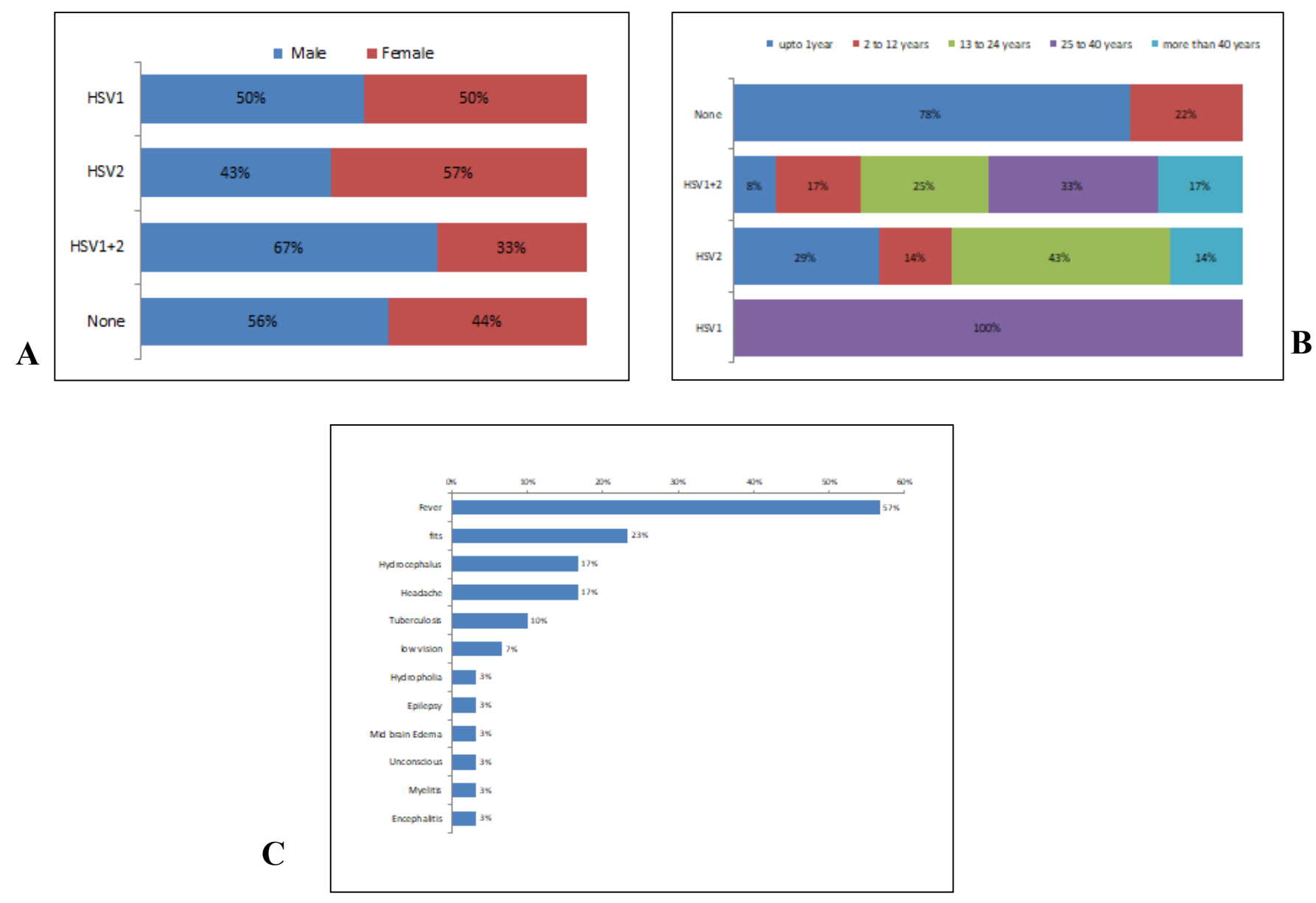

(A)Gender; (B) Age; and (C) Symptoms.

Figure 1. Demographic distribution of individuals showed HSV1, HSV2 and HSV1and 2 infections.

Table 2. Biochemical parameters associated with CSF showed Herpes simplex viral etiology.

\begin{tabular}{|c|c|c|c|c|c|}
\hline & \multicolumn{5}{|c|}{ Values are expressed as mean \pm SEMs } \\
\hline & HSV1 & HSV2 & HSV1+2 & None & $p$ value \\
\hline pH & $7.3(0)$ & $4.143(3.876)$ & $0.608(2.107)$ & $7.233(0.1)$ & 0.000 \\
\hline Protein (mg/dl) & $38.5(31.82)$ & $86.571(122.507)$ & $2.083(7.217)$ & $79.644(62.517)$ & 0.041 \\
\hline Glucose (mg/dl) & $45(24.042)$ & $26.857(27.462)$ & $5.083(17.609)$ & $27.156(19.984)$ & 0.030 \\
\hline RBC & $2(2.828)$ & $2.286(3.729)$ & $0.167(0.577)$ & $5.111(8.492)$ & 0.208 \\
\hline WBC & $46.5(61.518)$ & $16.429(32.878)$ & $0.417(1.443)$ & $74.111(197.387)$ & 0.504 \\
\hline Lympocytes & $27(38.184)$ & $11.429(30.237)$ & & $11.111(31.502)$ & 0.424 \\
\hline Neutrophils & $21.5(30.406)$ & $2.857(7.559)$ & & $11.111(31.502)$ & 0.353 \\
\hline DNA & $60.615(50.707)$ & $227.653(266.646)$ & $70.919(75.693)$ & & 0.147 \\
\hline
\end{tabular}

development. Due to the physical appearance of CSF clinicians may have not requested for the microbiological tests or these tests would be found negative if even requested which may lead to misdiagnosis. To establish this fact, we selected 30 bacteriologically negative CSF samples for the detection of HSV1 and HSV2 DNA from total cellular DNA extraction. HSV1 and HSV2 specific primers targeting the glycoprotein $\mathrm{G}$ gene were used for the viral detection. Presence of HSV2 was confirmed in (26.6\%) clinical samples of CSF whereas HSV1 was found in only (6.6\%) of samples (Figure 2). Taken all these facts together, it seems likely that CNS infections can be misdiagnosed and mistreated in the local government hospitals of Karachi. PCR for the existence of both bacterial and viral etiological agent should be performed along with routine CSF detailed report test to confirm the etiology.
Interestingly, (36.6\%) CSF samples demonstrated the mixed viral infection of HSV1 (Figure 2). A possible explanation for this result is that HSV2 is the cause of recurrent and ulcerative lesions of genital areas while HSV1 usually cause recurrent Herpes labialis, commonly called cold sores or fever blisters. The sores typically heal within $2-3$ weeks but HSV1 get dormant in the facial nerves. HSV establishes a latent infection in the peripheral nervous system. Lifelong latency of HSV in the neuronal cell is a characteristic feature of this virus. These neurotropic pathogens carry a repertoire of genes designed to sabotage the host's immune response. They can interfere with major histocompatibility complex (MHC) processing and secrete analogues of immune- regulatory molecules such as IL-10 [22]. Dual infections of HSV1 and HSV2 may be important because 


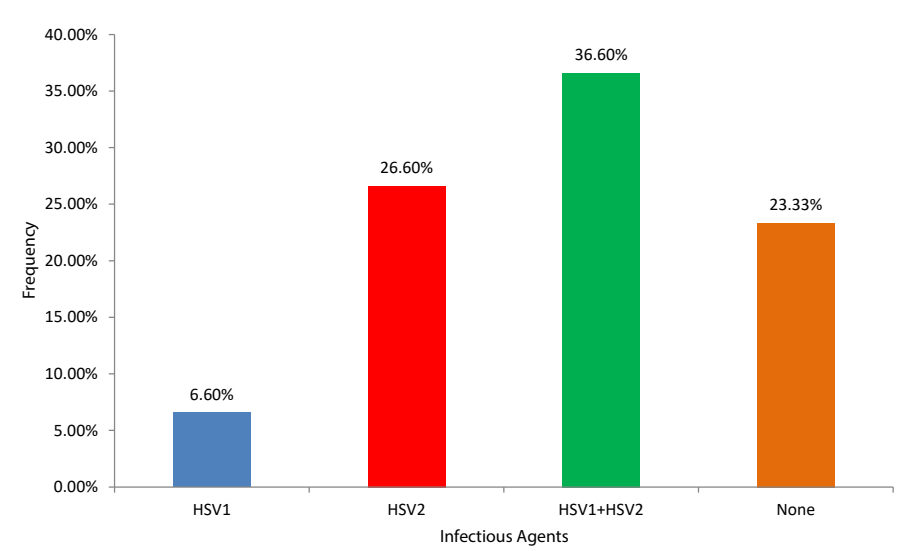

Figure 2. Frequency of individual Viral HSV1, HSV2 and HSV1+ HSV2 Viral Coinfection

primary infection of HSV1 modulates the course of HSV2 infection. Often, Latency of HSV is apparent in immunocompromised host and may be reactivated during other diseases where these viruses might not constitute the aetiopathogenic agents. Local or systemic stimuli trigger the reactivation of HSV. Reactivated infections can be symptomatic including gingivostomatitis, meningitis and encephalitis. Asymptomatic reactivations result in viral shedding [21].

In present study, it is significant to note that two-way ANNOVA analysis of the data of clinical investigation indicated two age groups of vulnerable persons i.e. infancy to youth (up to 1 year and 13 to 24 years respectively) subjects, the other one belong to old age (Figure 1B). The possible explanation of our findings is that, the infants may have acquired this infection from the HSV2 infected mothers as transmission may be occurred from a HSV2 positive asymptomatic partner. HSV2 meningitis in infants has the potential to cause significant morbidity and mortality. HSV2 being sexually transmitted infection is difficult to be recognized. However, presence of HSV2 infection in the young age reflects the activeness of these individuals in sexual relationship. Since most of the visitors of these government hospitals belongs to low socioeconomic status where early age marriages and sexual activities are common factor. Results of the present study can be further explained by the fact that many patients of Herpes infection may shed low levels of viruses continuously without demonstrated reactivation/ symptoms. These low socioeconomic individuals serve as the carriers of the virus and are responsible for dissemination of these viruses in their localities / communities. Results of the present study reflected high incidence of infection of HSV2 among the active and dynamic age group i.e. 13 - 24 years, whereas second most sensitive age group subjects belong to infancy (Figure 1B). This can be further explained by the fact that immunological status of the individuals may serve as an additional contributory factor for acquiring infection and/ or viral reactivation. Another possible source of dissemination of HSV2 infection could be hospital environment and staff. Hand disinfection of hospital staff is of paramount significance in preventing the transfer of pathogens.

DNA quantification profile of CSF samples rendered the high yield of the DNA concentration i.e. $802 \mu \mathrm{g} / \mathrm{ml}$ in the HSV2 infections (Table 2). This result may be explained by the fact that viral pathogen may stimulate the apoptosis in the infected cells which may lead to either loss or dysfunctioning of the cells of CNS. Neuronal and/or glial cell breakdown during viral infection yields end products which seem to be deleterious for the healthy cells and may facilitate the secondary infection. Our results are consistent with [23] who concluded that HSV induced neural cell oxidative tissue damage and cytotoxicity by activating microglial cell reactive oxygen species through a TLR2dependent mechanism.

Patient's history and physical analysis of the viral infected CSF samples reflected strongly elevated white blood cell count (WBCs) ( $>500$ cells/ $\mu$ l) in HSV1 infections with predominant neutrophils and moderately elevated protein concentration $(<1 \mathrm{~g} / \mathrm{L})$ (Table 2$)$ which is an indication of sever blood-CSF barrier disruption. Furthermore, profound increase in glucose CSF/blood ratio (> $50 \mathrm{mg} / \mathrm{dl}$ ) in $\mathrm{HSV} 1+2$ coinfection and protein concentration $(>1 \mathrm{~g} / \mathrm{L})$ in HSV2 along with increased number of red blood cells (RBCs) and lymphocytes (Table 2) supports the diagnosis of acute viral meningitis. Our findings can be further supported by the findings of Berger et al. [21] who reported that lower cell count and mixed pleocytosis are characteristically observed in viral infection or in partially or insufficiently treated meningitis.

Moreover, it is interesting to mention herein that analysis of the findings of clinical investigations indicated that HSV2 infection caused the elevation in protein level along with pronounced presence of blood cells i.e. WBCs and RBCs, immune cells i.e. lymphocyte and neutrophils and high cellular DNA yield (Table 2). Collectively, this highlights the blood vessel rupture, initiation of immune response and neurodegeneration in HSV2 infection. These interesting features additionally contribute in increasing the severity of HSV2 infection. In contrast, CSF samples found positive for coinfection of HSV1+2 showed less number of blood and immune cells (Table 2) when stained via differential leucocyte staining with moderate levels of proteins (Table 2). However, CSF glucose level (Table 2) was found increased in HSV1+2 coinfection which significantly indicate that this viral combination has profound effects on visceral organs specially pancreas that is mainly governed by the peripheral nervous system (PNS). Therefore, it can be concluded that implications of HSV2 infections on CNS whereas HSV1+2 coinfection affects PNS. Since CSF circulates within the ventricles of the brain and surrounds the brain and the spinal cord. Although CSF contains small molecules, salts, peptides, proteins and enzymes that play critical roles in many physiological processes. However, changes (concentration; modification of proteins and peptides) in its compositions reflect pathological processes in the CNS $[24,25]$. It is secreted in particular, from the ventricular choroid plexus and seeps down around the spinal cord. Therefore, this seepage facilitates the lodging of etiological agent to any part of the brain and spinal cord. Consequently, infection is not limited to the meninges but also effects the brain parenchyma (meningoencephalitis) [26], the ventricles (ventriculitis), spinal cord (Myelitis) [21,27] and even hydrocephalus $[28,29]$.

\section{Conclusion}

In conclusion, our results indicate a considerable prevalence of the Herpes simplex virus strains i.e. HSV1 and HSV2 solely and mixed infection of both the strains, in particularly in infants, young and old age people. An elevated WBCs count, predominance of immune cells i.e. lymphocytes and neutrophils and raised protein levels may serve as a valuable clue for the presence of HSV meningitis. Being an intracellular pathogen, HSVs are potent enough to traverse, lodge and cause the infection at different sites of the CNS therefore, timely diagnosis of this pathogen is pivotal. In nutshell, subsequent to the microbiological methods, use of molecular testing methods must be adopted by the medical diagnostic laboratories as a standard procedure to rule out the presence of viral meningitis. 


\section{Conflict of interest}

The authors of this manuscript declare that they have no conflict of interest.

\section{Authors' contributions}

Conceived and designed the experiments: NJ. Collection of the samples: AT. Experimental work: AT. Analysis of the data \& Conclusion: AT, NJ. Writing of the manuscript: AT. All authors read and approved the final manuscript.

\section{Financial support}

Indigenous scholarship provided by Higher Education Commission, Islamabad (HEC).

\section{Acknowledgment}

We would like to thank Higher Education Commission, Islamabad (HEC) for providing the financial assistance in the form of Indigenous scholarship that enabled us to complete this work feasibly in conducive manner.

\section{Refrences}

1. Somand D, Meurer W (2009) Central nervous system infections. Emerg Med Clin North Am 27: 89-100. [Crossref]

2. Zhang JR, Tuomanen E (1999) Molecular and cellular mechanisms for microbial entry into the CNS. J NeuroVirol 5: 591-603. [Crossref]

3. Drevets DA, Leenen PJ, Greenfield RA (2004) Invasion of the central nervous system by intracellular bacteria. Clin Microbiol Rev 17: 323-347. [Crossref]

4. Tang YW, Espy MJ, Persing DH, Smith TF (1997) Molecular evidence and clinical significance of Herpesvirus coinfection in the central nervous system. J Clin Microbiol 35: 2869-2872. [Crossref]

5. Johnson RT (1996) Acute encephalitis. Clin Infect Dis 23: 219-224. [Crossref]

6. Ho DD, Hirsch MS (1985) Acute viral encephalitis. Med Clin North Am 69: 415-429. [Crossref]

7. Gilden DH, Mahalingam R, Cohrs RJ, Tyler KL (2007) Herpesvirus infections of the nervous system. Nat Rev Neurol 3: 82-94. [Crossref]

8. Sköldenberg B, Alestig K, Burman L, Forkman A, Lövgren K, et al. (1984) Acyclovir versus vidarabine in Herpes simplex encephalitis: randomised multicentre study in consecutive Swedish patients. Lancet 324: 707-711. [Crossref]

9. Whitley RJ, Alford CA, Hirsch MS, Schooley RT, Luby JP, et al. (1986) Vidarabine versus acyclovir therapy in Herpes simplex encephalitis. N Engl J Med 314: 144-149. [Crossref]

10. Tang YW, Mitchell PS, Espy MJ, Smith TF, Persing DH (1999) Molecular diagnosis of Herpes simplex virus infections in the central nervous system. J Clin Microbiol 37: 2127- 2136. [Crossref]

11. Kupila L, Vuorinen T, Vainionpää R, Hukkanen V, Marttila RJ, et al. (2006) Etiology of aseptic meningitis and encephalitis in an adult population. Neurol 66: 75-80. [Crossref]
12. Sköldenberg B, Aurelius E, Hjalmarsson A, Sabri F, Forsgren M, et al. (2006) Incidence and pathogenesis of clinical relapse after Herpes simplex encephalitis in adults. J Neurol 253: 163-170. [Crossref]

13. Tyler KL (2004) Herpes simplex virus infections of the central nervous system:encephalitis and meningitis, including Mollaret's. Herpes 11: 57A-64A [Crossref]

14. Gaeta A, Verzaro S, Cristina LM, Mancini C, Nazzari C (2009) Diagnosis of neurological Herpesvirus infections: real time PCR in cerebral spinal fluid analysis. New Microbiol 32: 333-340. [Crossref]

15. Landergren M, Kyllernan M, Bergstrom T, Dotewal L, Lingstrom L, et al. (1994) Diagnosis of Epstein-Barr virus induced central nervous system infections byDNA amplification from cerebrospinal fluid. Ann Neurol 35: 631-635.

16. Studhal M, Richsten A, Sandberg T, Elowson S, Herner S, et al (1994) Cytomegalovirus infection of the CNS in non-compromised patients. Acta Neurol Scan 89: 451-457. [Crossref]

17. Xue C, Chen S, Lin Q, Zhou H, Huang C, et al. (2015) Double encephalitis with Herpes simplex virus type II and cytomegalovirus in an elder Chinese: a case report. Neuropsychiatr Dis Treat 11: 2833-2836. [Crossref]

18. Anderson NW, Sistrunk W, Binnicker MJ (2015) Simultaneous detection of Herpes simplex virus 1 and 2 in the cerebrospinal fluid of a patient with seizures and encephalitis. J Clinical Microbiol 53: 343-345. [Crossref]

19. Jawaid A, Bano S, Haque A, Arif K (2016) Frequency and outcome of meningitis in Pediatric Intensive Care Unit of Pakistan. J Coll Physicians Surg Pak 26: 716-717. [Crossref]

20. Taj A, Jamil N (2016) Detection of meningococcal meningitis in cerebrospinal fluid of patients with neurological disorders in government hospitals of Karachi. J Pak Med Assoc 66: 1418-1421. [Crossref]

21. Berger JR, Houff S (2008) Neurological complications of Herpes simplex virus type 2 infection. Arch Neurol 65: 596-600. [Crossref]

22. Amor S, Puentes F, Baker D, Valk P (2010) Inflammation in neurodegenerative diseases. Immunology 129:154-169. [Crossref]

23. Schachtele SJ, Hu S, Little MR, Lokensgard JR (2010) Herpes simplex virus induces neural oxidative damage via microglial cell Toll-like receptor-2. J Neuroinflamm 7: 35. [Crossref]

24. Yuan X, Desiderio DM (2005) Proteomics analysis of human cerebrospinal fluid. $J$ Chromatogr B Analyt Technol Biomed Life Sci 815: 179-189. [Crossref]

25. Heimer L (1994) The Human Brain and Spinal Cord, Springer, New York. p. 506

26. Gorospe WC, Rawls RA, Koch KA, Laos LF, Lambiase L, et al. (2004) Herpes brainstem encephalitis: a cause of intractable emesis. Hospital Physician 39-42.

27. Ohashi M, Bertke AS, Patel A, Krause PR (2011) Spread of Herpes simplex virus to the spinal cord is independent of spread to dorsal root ganglia. J Virol 85: 3030-3032. [Crossref]

28. Infinger LK, Varma AK (2014) HSV-2 Meningitis Presenting with Acute Hydrocephalus Ultimately Requiring Long Term CSF Diversion. JSM Neurosurg Spine 2: 1012.

29. Pina MA, Modrego PJ, Galve F (2006) Hepatitis, meningitis and hydrocephalus caused by Herpes simplex virus type I. American J Infect Dis 2: 36-38.

30. Enomoto Y, Yoshikawa T, Ihira M, Akimoto S, Miyake F, et al. (2005) Rapid diagnosis of Herpes simplex virus infection by a loop-mediated isothermal amplification method. J Clinical Microbiol 43: 951-955. [Crossref]

Copyright: (C2018 Taj A. This is an open-access article distributed under the terms of the Creative Commons Attribution License, which permits unrestricted use, distribution, and reproduction in any medium, provided the original author and source are credited. 